Kohl: a Journal for Body and Gender Research

Vol. 4, No. 1 (Summer 2018)

\title{
Institutional Surveillance and Policing: \\ Documenting Student Activism at AUB
}

Sana, Tee Mk, Raed, Katya, and Rana 
The student movements at the American University of Beirut (AUB) have long and rich histories. Some of its main waypoints since 2014 were the STFI (Stop Tuition Fees Increase) protests, AUB Divest, Students against Nestle, the Red Oak Club tent during the 2015-2016 protests, and the more recent Boldly G-AUB campaign. It is mainly those actions - which are most discussed among the participants of this conversation - that instigated responses from the administration's part, with the aim to police and discipline student activism.

In 2014, the AUB administration decided to raise the tuition fees by $6 \%$, after a series of tuition increase that started in 2010. This decision led to students protesting the increase, accusing the university of lack of transparency, and demanding the resignation of the president and administration members accused of corruption. The protests, held in 2014, were the largest in the recent history of AUB, and included a strike. The movement ended after a compromise was reached between students and the administration, whereby the administration agreed to increase the tuition for new students only, and by a lesser percentage. In 2015, a group, under the name "AUB Divest," was created to pressure the university to cut any ties (contracts and invitations) with companies who support the occupation of Palestine. The group released many statements and petitions, and protested the installment of a Nestle Toll House on campus, as well as the presence of many companies that support the zionist state at university-held job fairs. As the group became inactive after a year and a half, a new group was initiated, "Students against Nestle." This group focused mainly on pushing the university to cancel its contract with Nestle, and more or less on issues related to pro-Palestine activism on campus. In November 2015, as protests were held in Lebanon during the garbage crisis, members of the Red Oak Club, a leftist student club, set up a tent in front of West Hall. They were protesting the administration's refusal to cover students, staff, and faculty injured during the protests under its Health Insurance Plan (HIP). The tent was also a space for sharing, discussing and linking students to the civil movement happening off-campus. After 13 days of camping, the administration finally agreed to cover students as part of the HIP.

In 2017-2018, tensions between the administration and the student body were renewed. The administration decided to withdraw the stipends usually paid for graduate assistants (GAs), as a compensation for their labor, starting Spring 2016-2017. Graduate students formed a group, Boldly G-AUB, to pressure the university to reinstate the stipends. The group started with negotiating a new GA policy with the administration. However, as the administration showed no serious response to students' demands, Boldly GAUB decided to set a tent on College Hall towards the end of Fall 2017-2018, after holding protests on campus and releasing many statements. The tent aimed to achieve three main demands: (1) stipends indexed against the concrete cost of living in Beirut (minimum 400\$); (2) two-year GA contracts (subject to conditions); and (3) waiver of university fees (technology, social activities, HIP). Not only did the administration not respond to the demands, but it retaliated by withdrawing the scholarships of $14 \mathrm{GA}$ students involved in Boldly G-AUB, issued them dean's warnings, and forcibly removed the tent after nine days of its setting. In parallel with the GA issue, the administration censored the issue of Outlook, the independent student publication, for the week of September 25, 2017. The decision was held unexpectedly 
and without prior consultation with the Outlook board, and came after direct criticism from Student Affairs to the content of Outlook. Although this was not the official reason for censoring Outlook, the administration's criticism was directed towards articles related to Professor Steven Salaita's issue, and the GA issue. This decision was unprecedented, as Outlook never stopped publishing since its establishment, except for reasons related to the civil war.

This informal conversation was held on May 22, 2018, and lasted for two hours. Five recently graduated AUB students, who were directly or indirectly involved with student activism on campus in the past few years, discussed institutional mechanisms of policing and surveillance that permeate to educational structures and campuses. These excerpts do not claim to represent the student body at AUB or universities across Lebanon. Instead, they hope to provide insights into the structural issues of institutional ecosystems, and to historicize and document glimpses of students' activism and aspirations for liberation, democratization, and anti-elitism.

Pseudonyms were used to protect the identity of those who participated in this conversation. 
Tee Mk: I feel that student activism sort of crested at the tuition protests. After the settlement between the administration and the student representatives, things went downhill: being involved in any kind of overt activism became considered marginal. During that time, actions by students involved the AUB divest, the protest that happened outside the Nestle Toll House, and the Red Oak tent that was put up in protest to AUB not covering students that went to the garbage protest under the Health Insurance Plan (HIP). When the Graduate Assistantships (GA) issue and the Outlook issue happened at the same time, it made people sort of wake up and ask what was going on at the university. I personally think both issues require that we look at labor, or the institution's idea of labor and what they consider as labor that should be paid. And I feel that whether in the GA or Outlook case, labor got swept under the rug in favor of more sensationalist discourses like the suppression of freedom of speech.

Katya: In terms of activism, there definitely was outrage regarding the fact that Outlook had been canceled for the first time in 25 years, and was not allowed to publish for one whole week, but I do not think it had the same effect in mobilizing like the GA issue did. I believe that labor plays a huge role, in the sense that Outlook was once part of the work-study program. All members of the board used to be paid, but that policy eventually died out, and so nowadays the Outlook Board is hired and expected to produce approximately 25 issues, averaging 28 pages each, throughout two semesters without any compensation. This is not to say that Outlook members want anything in return for their work, but I brought this up to highlight how the two student issues are interlinked. GAs and members of Outlook both experienced forms of surveillance and policing. Although sparked from different causes, their struggles ultimately overlapped at times, because they both endured the same process with the administration.

Raed: I have a range of experience in student activism because I was part of LAU (Lebanese American University) Beirut then LAU Jbeil before going to AUB. I don't think we can separate university policing from the general political situation in Lebanon. When we were organizing an election campaign at LAU Jbeil, it was the first time that a non-partisan organized group was running. The intimidation techniques of the parties were incredibly frightening and stressful for us. You can see how much power and resources they really have, and their threats are not empty words. They can simply go up to a person and beat them up because they have the support of their parties, which shapes the context of the university itself. For example, the Dean of students in LAU Jbeil wanted to negotiate between the students and the faculty because he did not want to upset the political parties; he wanted to give them a bit, but not too much power. We also have to look at separation between the administration, students, and faculty. If the students and faculty do not generate marketing and a "good image" for the university, they are left to fend for themselves. For example, in my department, faculty does not get paid as much as in other departments like the business 
school or schools that are considered more important in terms of production, which says a lot about what you do and how it is defunded and not invested in. We are basically asked to put our efforts in production and not care about the discipline we're studying. This also holds true for faculty, as many do not receive the administration's support for the academic work and the research that they do. So who is the university for, if it is not for students and faculty?

Tee Mk: I think in terms of political parties, as soon as we started organizing for the GA issues, we heard whispers that the administration was basically dismissing us as one political party or the other. For one, the separation between "student activism" and Lebanese political parties is kind of interesting: it ignores the fact that we could be partisan, and also have genuine concerns about whether our labor is being compensated. During AUB elections, all political parties in Lebanon operate at all levels of the student body, and no one says anything. If the administration can monitor and regulate the actions of political parties on campus through student government and representation, then partisanship is fine. But when it is not within the structure that the administration has approved of, the idea that political parties are influencing students becomes threatening when it comes to students putting up a tent, or raising concerns, or asking about the salaries of the administrators at AUB and how much are they making.

Rana: In the context of AUB elections, it doesn't matter whether the candidates are from the sectarian parties or considered the "cool" liberal people. At the end of the day, everyone, even those who are supposedly progressive and working for students' rights or issues, are contained by the administration. That is why they are less policed than student movements. The GA issue was about students and administration, nothing else, but they have distorted the narrative from students versus administration to sectarians versus seculars.

Sana: $\quad$ Absolutely, our causes get coopted by the administration and become used as a marker of democracy. Take freedom of speech for instance: the administration prides with AUB being the place where radical ideas about for example feminism are welcomed, where we can attend a conference about historical materialism, unlike other institutions. But if we seriously look at those instances critiquing the politics of the administration, how do they react to that and how do they treat dissent?

Katya: Juliette, the 2017/2018 editor-in-chief of Outlook, wrote a piece about activism as one of her first editorials in Outlook at the beginning of the academic year, but was subsequently called in to speak to the dean of student affairs after it had been published. He said that what she wrote was an attempt to incite violent riots on campus, when all she was trying to do was to question why students have become so apathetic today, citing fear of the administration as one reason. And the administration proved her point because Outlook was cancelled just the following week. So the fact that the institution prides itself so much on freedom of speech as one of its core values is rather ironic given the evidence. 
Tee Mk: I think that the Outlook issue was strike one. There was also the story of Mariam Dajjani, which was coopted by the administration. She was a hijabi student in Samir Khalaf's class; when she asked him to repeat what he had said during a lecture, he yelled at her and said that her wearing the hijab is the reason why she could not hear him. She posted the story on AUB Guru, the Facebook group for AUB students, and it snowballed into a major issue, with Samir Khalaf being forced to retire at the end of last semester. People organized a protest in support of Mariam Dajjani. The AUB Code of Conduct says that we need to apply for permission to organize protests. So if I want to protest something, I have to file paperwork, and give it to the Dean of Student Affairs. Some of the protest's organizers were scared to defy this Code of Conduct, so they emailed him, and he asked them to call the protest off and negotiate with him.

Katya: $\quad$ He threatened them.

Tee Mk: $\quad$ Yes, with disciplinary action. One of the organizers posted the screenshot of this email on the AUB Guru group, which led to even more backlash and further motivation to hold the protest. When the protest finally happened, the Dean of Student Affairs showed up and held a sign that said "AUB stands for diversity." This is what is meant by cooptation. There was even a picture of him protesting on Twitter that was retweeted by the President of the university. And then a week later, Outlook got canceled. Cooptation is directly proportional to how mainstream the issues become. Stepfeed and other publications wrote about the Mariam Dajjani issue; it became this huge scandal. So the administration's approach to dealing with it was to coopt it.

Sana: I think the story of Mariam Dajjani was very much supported by Islamic groups and Hezbollah. And going back to the history, Dorman's administration was more lenient. Of course the corruption files of AUBMC were leaked and Dorman resigned. Fadlo Khuri replaced him as the president, the strongman of the university.

Tee Mk: The "Arab" strongman.

Sana: $\quad$ He started with budget cuts and took increasing policing measures, then proceeded to rounding up leftists who are engaged, like Rania Masri.

Tee Mk: $\quad$ Or Steven Salaita. The same issue of Outlook on student activism also included an opinion piece on Steven Salaita and the lack of freedom of speech on campus. A student who worked in the administration at the time asked to write a counter piece. Not only was her piece slanderous to Salaita as a person, but she also cited the university's town halls as a marker of "democracy." It makes me think that the reason Outlook was cancelled had more to do with personal vendettas where the administration is concerned rather than anything in 
the editorial directly inciting "violent riots" on campus. This targeting is ideological and political, and spread across the board with the GA issue and with individuals on the Outlook board as well.

\section{Mechanisms of Surveillance and Control}

Raed: $\quad$ The way we talk about university now is very different from what people thought a university was a couple of years ago. Universities were perceived as a space to engage with students and professors and to learn and be exposed to student organizing. Freedom of speech is only permitted for a certain kinds of "speech." If one looks at the language Fadlo Khuri uses in his weekly President's Perspective emails, such as most used words and recurrent themes, they would find out that they are marketing related. AUB is described as the beacon of hope that is changing the region and the world. AUB for Refugees for example makes it seem as if AUB, an elitist institution, is improving the livelihood of refugees in Lebanon.

Katya: $\quad$ He calls refugees "guests."

Raed: $\quad$ Their struggles are reduced to ways we can talk about them; it is discursive. Would they even be allowed into the university if they cannot afford it, not to get degrees but audit classes? There are many empty chairs in our classrooms. And if it is such an inclusive university, why are IDs checked at the gate? So to go back to the point of marketing, a lot of our tactics as student activists have been considered "harmful" to the reputation of the university. And AUB is very sensitive about its reputation; it is like a company selling a product. If their reputation gets tarnished, they will get less money, so they maintain it by suppressing dissent instead of working through what went wrong in the first place. There is so much attention that needs to be placed on the business aspect of this university in particular, because the President's Perspective is pure advertisement. How long has Fadlo Khuri been president?

Katya: $\quad$ Almost three years.

Raed: $\quad$ Three years and nothing bad that he wants to share with us? It is just us who become the problem.

Tee Mk: It is all a media campaign like you said: pictures of meetings with the president of Trinity College Dublin, statements about inter-university cooperation, all are buzzwords. And the donors are the ones who read those updates. The administration does not care about the students, only about the donors. With the GA issue, nothing was working: sit-ins or protests would only gather verbal support from some students and faculty who would say "we support you but we cannot say anything." When we lost our GAships, there was suddenly something 
for everyone to be outraged about. The primary organizing goal was to capitalize on this issue and contact the media. The second was to email donors. We created a Google doc and an excel sheet with every media publication that covered the issue and the article link and sent them to the donors. It seems it is the only way to get things done these days: hit where the money is coming from. But that made me unhappy, because it should be more than just about money or image. Unfortunately, this is what it has come to now.

Sana: $\quad$ After the student by the sit-in tent was forcibly removed, I thought that something would happen, that the administration would pull back a little bit. Instead, to my surprise, there was a meeting between the University Students Faculty Committee (USFC) and the administration where the video ${ }^{1}$ was played and the attendants discussed whether or not this was violence. How much do students have to get hurt for it to be considered violence? It is the logic of quantifying harm so that it hits a certain threshold to be called violence. That the administration is willing to resort to these methods to silence people is violence.

Tee Mk: $\quad$ The night of the tent incident, they locked down campus and would not let us, the students, in. This is something that they have not done since the civil war. It is really dangerous to treat students that way: the complete campus lockdown was planned to take the tent, which had the two female students in it, down without anyone seeing. And I cannot believe that that fact was not even brought up in this meeting with student representatives who are supposed to represent us.

Raed: $\quad$ Maybe we can ask what the techniques of power that a university uses to maintain this money-generating system are. Who is the university? It is not the staff, but the people who decide where the money goes and how it is spent. From my perspective, a first answer is the Dean of Student Affairs. What do they do? How can they do what they do? And what is their job? Part of the reason why people are not so comfortable organizing is that if they kick us out and there isn't outrage, people cannot afford to have an education in the absence of scholarships. The system works to their advantage. The student handbook states that to organize a protest, you need permission, which is different than a notification. We want the administration to know what we are demanding, but when it is a permission, it clearly shows that the students have no control over the space. An AUB alumni told me that after the civil war, they used to close classrooms and occupy buildings. We are obviously operating in a different context; were we to occupy buildings, the administration would probably ask the security to physically remove us out of the campus. The buildings are neither for students nor for faculty.

Tee Mk: $\quad$ Tenure for faculty had not been in place since the civil war but was just reinstated. In terms of policing faculty, it is a really useful mechanism for the university to control what the faculty

1 https://www.facebook.com/events/546282505714664/permalink/546315452378036/ 
says and does, and who they support openly or quietly. All of the AUB professors are supposed to apply for tenure now, and the ones that do not will simply not be not approved and asked to leave. The administration gave tenure to themselves first - the president, the provost, etc., and now they are figuring out which faculty members are on their good side and which faculty members are not. This is why we did not get any explicit faculty support, even though at the end of the day, our labor as graduate assistants is benefiting the faculty, as they are the ones who are directly using our time and work. On the one hand they are complicit in our exploitation, but on the other hand, when you see these mechanisms of surveillance and control, they cannot be blamed, as so much is at stake, including their families' livelihoods and education. So that mechanism works to fragment the university: faculty and students stop standing together. They are not against each other, but they are not together either. Faculty start seeing their issues as faculty issues, and students start seeing their issues as student issues, rather than a collective struggle.

Raed: $\quad$ Some faculty did show the student movement their support, and they had to carefully measure the ways in which they expressed that support. The faculty is also policed like you said, and I do not consider faculty our enemies. I think the administration is shaping faculty behavior, and the faculty is well aware of that, as in-class discussions have shown. The commonality here is the production of precarity for both students and faculty because there is so much to lose; we worry about what else there is to lose: no tenure, no fixed employment contracts, no free education. We have so little, and asking for more comes at the expense of the little we already have.

Rana: $\quad$ Another mechanism of control is to transform a political issue into a personal attack, and retaliate by targeting and distorting the personal lives of the students. When I joined the organizing around the GA issue, the administration accused of doing Hezbollah's bidding on campus. I am known on campus to be with the Syrian revolution and in conflict with Hezbollah and by extension with my family because of my political views. Their accusation was completely unrealistic.

Katya: $\quad$ The fact that they directly attack who you are as a person and use character assassination strategies says a lot. Juliette was told she was a liar devoid of morals or values. This tactic is no short of intimidation with the aim to silence, in addition to injecting doubt amongst the members. This was why so many people cracked under pressure and ended up quitting. The administration even sent a mass email to the whole university saying that the Outlook team had lied about matters relating to their cancellation. They hadn't. 


\section{Gendered Dynamics and Hierarchies}

Katya: It is also very important to note the gendered dynamics at play. The Outlook Board was mainly composed of women/women-identifying individuals. In a meeting with the administration, there was obviously a blatant disregard for what the women had to say, and the dean once went so far as to suggest listening to one of the only male board members present, rather than to take into account what the women had to say, because he sounded like "the voice of reason." Juliette was also told she was easily swayed and had no agency to think for herself or make her own decisions - a very dangerous assumption often made about women.

Tee Mk: Even with the GA issue, when we were mobilizing, administrators would single out some men in our group and accuse them of inciting protests single-handedly, without so much as a glance at us. For them, activism can only be instigated by men. Because of these gendered aspects, when another two women and I put up the tent, the men stood around us and linked arms. We knew the administration would not react violently if and when women are involved because of their patriarchal and paternalistic mindset.

Sana: $\quad V_{i d e o{ }^{2}}$ show that the security guard told women by the tent that they will not be more difficult than the male student involved in the mobilizing, that he was "the best of them." The student played along the gendered dynamic and told him: "so you have waited until you saw two women sitting alone in the tent to come and pretend to be macho." To which he replied: "no, here we have gender equality." And speaking of the methods used by authorities, a rumor circulated that students would file a complaint against the tent under the alibi that it is bothering them to give the administration a legitimate reason to bring it down.

Tee Mk: This comes back to the earlier point of installing doubts and looking for differences among the students they can capitalize on, so that the students fight with each other. When we started negotiating with the administration, the elections had not happened yet, so we did not have any graduate representatives. As soon as the elections happened, they demanded to only speak to the "legitimate" representatives that were elected, not the "rogue" actors. Then they started trying to pit the representatives against the grassroots activists.

Sana: $\quad$ They became explicitly against students protesting; the vice president of the student representatives told them that she wanted this rally to end.

Katya: $\quad$ This I think reinforces a hierarchy between students, obviously facilitated and enforced by the administration. But when the students start believing it themselves, the whole narrative

2 lbid. 

only response.

Tee Mk: The USFC posted a statement online to support students' rights to freedom of speech and to condemn the administration's decision to revoke the GAship of nine students, who were also given warnings. It wasn't distributed through the official channels because, since USFC is a union of students and faculty, they could not get a meeting with the faculty representatives beforehand. We convinced them to publish the statement as students anyway. The VP, who also came to the protest, was personally contacted by the dean of students, who told her she was threatening the integrity of student government and democracy. Within half an hour the statement was removed and never put back. That created more divisions with representatives who, at the end of the day, are also students affected by the issue itself.

Sana: I may have a bit of a radical position concerning USFC, because I have never seen it take a stance with the students. On the contrary, this body has always worked as the eye of the administration. And going back to the cooptation of causes, the more progressive and politically correct the administration's discourse, the more it scares me, because they spread the notion that student activism is no longer necessary. We become mere troublemakers, and the administration veers the students towards more "peaceful" bodies they can join.

\section{Performative Democracy and Unions}

Katya: $\quad$ Student clubs. That is their definition of student activism. They pride themselves on how "active" their students are because there are so many clubs, none of which would or could exist without administrative bureaucracy, and many of which must endure involvement from the administration. This is counterproductive.

Raed: $\quad$ AUB sometimes seems like a personal project of main administrators. Of course they take it personally because it is personal; they are making money off of it.

Tee Mk: They think AUB is their front yard, their personal playground.

Raed: $\quad$ They use democracy as if we have democracy; it is performative. For example, it is not easy to have the USFC become the arm of the administration. But they think that if you get elected, you would want to keep your privileges as part of the administration. If you are too radical, then they let you off. You lose that climbing of the social ladder and you can't put it on your $\mathrm{CV}$. You become the masses. As for the permission to protest and other bureaucratic hurdles, they know very well that the bureaucracy is not functional, so they use these techniques to keep students down. Student clubs are seen as depoliticized, and if you are 
doing a movement like a student union, it is not allowed, because, according to them, we

already have our own student government. Why can't we have a union that is grassroots? The same parallels apply to NGOs: they are also depoliticized and seen as events holders. If an NGO wants to do something more radical, it is targeted. I was not at the tent when I got the warning; everyone involved knew that I was supportive, but I was not on campus that night.

Tee Mk: $\quad$ But you were spotted around the tent, which is why you got the dean's warning.

Raed: I I no not think it is that. I expressed a lot of outrage about the administration on social media, and then I shared personal pieces and statuses that I made public on Facebook. An hour later, I got the email revoking my GAship. It was a different timing than most people who got the email. I think social media is surveilled.

Tee Mk: $\quad$ We talked a lot about forming unions, whether an AUB union or a graduate students one all over Lebanon. It is impossible. If we apply through the government, we need to represent graduate students and some are foreigners. We even thought about registering as an NGO, but we do not want the union to be an NGO. We could also register as a chapter of an association in the US, like Faculty United, a faculty union that is also a chapter of the American Association for University Professors (AAUP). But even Faculty United has become depoliticized. So we were worried that had we become a chapter of a student association, we would end up depoliticized as well.

Raed: $\quad$ To think of modes of resistance, a union would be one, as long as it is not merely performative but has material effect. Another is the communication between us, the alumni, and the activists at the university. We need to find commonalities of organizing, not just at university, but as part of movement building in Lebanon.

Sana: $\quad$ About the unions, I think there are some attempts now. But as long as we are still thinking in the same vein of being validated by the administration, it would remain performative. Unions forming today, as they aim to be very structured and to approve everything, have not mobilized around any cause so far, focusing instead on social media campaigning. Unions with rigid structures don't work, and from my experience in the student movement and other movements, I have found that communicating with and hearing each other work better than structures that lack flexibility. 
Kohl 4.1

\section{Issues of Class and Documenting Struggles}

Rana: $\quad$ About the similarities between policing outside of the university and inside of it, the idea of the tent was embarrassing to the administration. They felt we were occupying space like "gypsies;" it was a very classist discourse.

Tee Mk: The first week the tent was up, nobody said anything because the provost and president were not on campus. Then the president showed up one day; there was one woman sitting outside of the tent and another one sleeping inside. He said that they were littering, that this was litter.

Raed: Like the homeless. To go back to the union, we have a lot of experience and knowledge that is not shared with people coming into the universities. That allows the administration to maintain the imbalance of power, so maybe bringing alumni and students together for knowledge sharing workshops and strategy discussions would be very useful.

Sana: If we look at the available potential, and at how things are being done, it is very shocking. We have a syndicate for workers at AUB that struggled to become strong, and the students barely know about its existence. We are overlooking so many opportunities to network with them, to really create a collaboration.

Tee Mk: $\quad$ To add onto your point, when we had the tent up, we had so much support from different staff members, whose positions I won't mention. The sense I got was that they are in such precarious positions that they would only express their support quietly. All the staff at AUB, including security and administrators, sign a clause in their work contracts that prohibits them from speaking out against the university. At the end of the day, students are protected more than anyone else in the university community because we are consumers. We are consumers of the product that AUB is selling.

Raed: There is a lot of critique as to who is active, which is useful because it tells us what to do, but it often reduces us to this position. They also silence us, because we cannot do things anymore, and we already cannot do much. So what are the ways to use our critiques in ways that produce action? We are close to being alumni already, and all we talked about is valuable for the new students. We need to document it; this history needs to be recognized. 